\title{
ANALYZING STUDENTS' READING ABILITY TO COMPREHEND TEXTS AT GRADE V OF GROUP I OF ELEMENTARY SCHOOLS AT DISTRICTS TAMPAN PEKANBARU
}

\author{
Azri Muzhar \\ Universitas Riau, Pekanbaru, Indonesia \\ azrimuzhar16@gmail.com
}

\begin{abstract}
This was a descriptive quantitative study. The purpose of this study was to determine the reading comprehension ability of fifth grade students of Group I of Elementary Schools, Kecamatan Tampan, Pekanbaru. The data were collected through a test in the form of multiple choice questions, totaling 50 items. The validity of the research was performed by experts. The samples in this study were 343 students coming from 5 schools, namely SDN 37 Pekanbaru, SDN 147 Pekanbaru, SDN 192 Pekanbaru, SDN 188 Pekanbaru, and SDI Brilliant Pekanbaru. The results showed that the average indicator of understanding the meaning of the word was 61.34 with sufficient category, the indicator for understanding the content in the paragraph was 61.72 with sufficient category, the indicator of determining the main idea was 64.72 with sufficient category, the indicator in the correct order of sentences was 63.09 with sufficient category, and the indicator of concluding the reading text was 62.36 with enough category.
\end{abstract}

Keywords: reading ability to comprehend texts

\section{ANALISIS KEMAMPUAN MEMBACA PEMAHAMAN TEKS SISWA KELAS V SEKOLAH DASAR GUGUS I KECAMATAN TAMPAN KOTA PEKANBARU}

\begin{abstract}
ABSTRAK
Penelitian ini merupakan penelitian kuantitatif deksriptif. Tujuan dari penelitian ini adalah untuk mengetahui kemampuan membaca pemahaman teks siswa kelas V Sekolah Dasar Gugus I Kecamatan Tampan Kota Pekanbaru. Teknik pengumpulan data adalah tes berbentuk soal objektif atau pilihan ganda yang berjumlah sebanyak 50 butir soal. Validitas penelitiannya telah divalidasi oleh ahli. Sampel dalam penelitian ini 343 siswa yang terdiri dari 5 sekolah yaitu SDN 37 Pekanbaru, SDN 147 Pekanbaru, SDN 192 Pekanbaru, SDN 188 Pekanbaru, dan SDI Brilliant Pekanbaru. Hasilnya menunjukkan bahwa rata-rata indikator memahami makna kata yaitu 61.34 dengan kategori cukup, indikator memahami isi dalam paragraph yaitu 61.72 dengan kategori cukup, indikator menentukan ide utama yaitu 64.72 dengan kategori cukup, indikator mengurutkan kalimat yang benar yaitu 63.09 dengan kategori cukup, indikator menyimpulkan teks bacaan yaitu 62.36 dengan kategori cukup.
\end{abstract}

Kata Kunci: kemampuan membaca pemahaman teks

\begin{tabular}{|c|c|c|}
\hline Submitted & Accepted & Published \\
\hline 19 Agustus 2020 & 15 April 2021 & 14 September 2021 \\
\hline
\end{tabular}

\begin{tabular}{|l|l|r|}
\hline Citation & $:$ & $\begin{array}{r}\text { Muzhar, A. (2021). Analyzing Students' Reading Ability to Comprehend Texts at Grade V of Group I of Elementary } \\
\text { Schools at Districts Tampan, Pekanbaru. Jurnal PAJAR (Pendidikan dan Pengajaran), 5(5), 1252-1259. DOI : } \\
\text { http://dx.doi.org/10.33578/pjr.v5i5.8114. }\end{array}$ \\
\hline
\end{tabular}

\section{PENDAHULUAN}

Bahasa memiliki peran sentral dalam pengembangan intelektual, sosial, dan emosional siswa dan penunjang keberhasilan dalam mempelajari semua bidang studi. Fungsi utama bahasa adalah sebagai alat komunikasi dengan orang lain. Bahasa adalah bunyi yang dihasilkan oleh alat ucap manusia dan menimbulkan makna. Prinsip pengajaran bahasa adalah agar siswa terampil berbahasa. Bahasa Indonesia merupakan bahasa formal dan resmi yang wajib dijaga keberadaannya. Pembelajaran bahasa dan sastra Indonesia di SD adalah pembelajaran yang dilaksanakan secara terpadu dan dapat diarahkan untuk meningkatkan kemampuan peserta didik dalam berkomunikasi bahasa Indonesia dengan baik dan benar secara lisan maupun tulisan, serta menumbuhkan apresiasi terhadap hasil karya kesusteraan manusia Indonesia, mengungkapkan 
ide secara runtut, logis dan konstektual sehingga gagasan itu berguna bagi siswa dan masyarakat di sekeliling mereka. Oleh karena itu pembelajaran Bahasa Indonesia mendapatkan peran penting untuk pendidikan di Indonesia karena merupakan bahasa resmi di semua bidang. Standar kompetensi mata pelajaran Bahasa Indonesia merupakan kualifikasi kemampuan minimal peserta didik yang menggambarkan penguasaan pengetahuan, keterampilan berbahasa, dan sikap positif terhadap bahasa dan sastra Indonesia. Keterampilan yang dimaksud adalah: keterampilan menyimak, keterampilan berbicara, keterampilan membaca, dan keterampilan menulis.

Membaca merupakan suatu kegiatan atau proses kognitif yang berupaya untuk menemukan berbagai informasi yang terdapat dalam tulisan. Hal ini berarti membaca merupakan proses berfikir untuk memahami isi teks yang dibaca. Oleh sebab itu, membaca bukan hanya sekedar melihat kumpulan huruf yang telah membentuk kata, kelompok kata, kalimat, paragraf dan wacana saja, tetapi lebih dari itu bahwa membaca merupakan kegiatan memahami dan menginterpretasikan lambang, tanda, tulisan yang bermakna sehingga pesan yang disampaikan dapat diterima oleh pembaca.

Burns, dkk. (Rahim 2011) mengemukakan bahwa kemampuan membaca merupakan suatu yang vital dalam suatu masyarakat terpelajar. Namun, anak-anak yang tidak memahami pentingnya belajar membaca tidak akan termotivasi untuk belajar. Belajar membaca merupakan usaha yang terus menerus, dan anakanak yang melihat tingginya mulai (value) membaca adalah kegiatan pribadinya akan lebih giat dalam belajar dibandingkan dengan anakanak yang tidak menemukan keuntungan dari kegiatan membaca. Membaca semakin penting dalam kehidupan masyarakat yang semakin kompleks. Setiap aspek kehidupan melibatkan kegiatan membaca. Disamping itu, kemampuan membaca merupakan kehidupan sehari-hari manusia.

Membaca adalah suatu proses yang dilakukan serta dipergunakan oleh pembaca untuk memperoleh pesan yang hendak disampaikan oleh penulis melalui media kata-kata atau bahasa tulis, suatu proses yang menuntut agar kelompok kata yang merupakan suatu kesatuan akan terlihat dalam suatu pandangan sekilas, dan agar makna kata-kata secara individual akan dapat diketahui. Kalau hal ini tidak dipenuhi, maka pesan yang tersurat dan tersirat tidak akan tertangkap atau dipahami, dan proses membaca itu tidak terlaksana dengan baik (Hodgson dalam Tarigan 2008).

Salah satu jenis keterampilan membaca adalah membaca pemahaman. Maka dari itu pengenalan dasar-dasar kemampuan membaca pemahaman sudah diajarkan sejak tingkat pendidikan sekolah dasar. Namun dalam kenyataan sekarang banyak siswa memiliki minat baca yang kurang atau sangat rendah. Hal ini disebabkan kurangnya keterampilan membaca siswa. Akibatnya dengan keterampilan membaca yang terbatas tersebut siswa sekolah dasar menjadi kurang dapat memahami bahan bacaan yang mereka baca. Akibatnya mereka malas membaca.

Hal tersebut terlihat bahwa masih banyak siswa yang belum mampu memahami isi bacaan. Dimana siswa hanya sekedar membaca tanpa mencari tahu maksud atau inti dari isi teks yang mereka baca. Saat membaca siswa juga kurang memahami isi bacaan karena hanya sebatas membaca dari awal hingga akhir dan masih kesulitan menyimpulkan isi teks dari beberapa kalimat. Siswa belum dapat menentukan ide pokok pada suatu bacaan, belum mampu menjawab pertanyaan dan belum mampu membuat pertanyaan berdasarkan teks yang mereka baca selain itu siswa belum mampu mengurutkan beberapa kejadian dalam suatu tes bacaan. Siswa sering tidak kosentrasi sehingga siswa kurang tertarik dan malas membaca.

Berdasarkan latar belakang yang telah dikemukakan, maka rumusan masalah dalam penelitian ini adalah bagaimanakah kemampuan membaca pemahaman teks siswa kelas V SD Gugus 1 Kecamatan Tampan Kota Pekanbaru? Tujuan dari penelitian ini adalah untuk mengtahui dan mendeskripsikan kemampuan membaca pemahaman teks siswa kelas V SD Gugus 1 Tampan Kecamatan Tampan Kota Pekanbaru. 


\section{METODE PENELITIAN}

Penelitian ini termasuk jenis penelitian kuantitatif yang bersifat deskriptif. Metode kuantitatif merupakan suatu proses pengetahuan menggunakan data berupa angka sebagai alat menganalisis keterangan mengenai apa yang ingin diketahui.

Penelitian deskriptif adalah penelitian yang digunakan untuk menganalisis data dengan cara mendeskripsikan atau menggambarkan data yang telah terkumpul sebagaimana adanya tanpa bermaksud membuat kesimpulan yang berlaku untuk umum atau generalisasi. Penelitian ini tidak mengadakan manipulasi atau pengubahan pada variabel-variabel bebas, tetapi menggambarkan suatu kondisi apa adanya.

Dapat ditarik kesimpulan bahwa penelitian kuantitatif deskriptif merupakan penelitian yang bertujuan untuk memberikan suatu gambaran keadaan atau situasi yang terjadi pada saat sekarang atau telah lampau dengan jelas tanpa merubah hasil penelitian dan disajikan dalam bentuk angka.

Pada penelitian ini, peneliti ingin memberikan gambaran tentang bagaimana capaian Kemampuan membaca pemahaman teks Siswa Kelas V SD Gugus I Kecamatan Tampan Kota Pekanbaru. Dalam penelitian ini peneliti menggunakan sampel secara Sampling Jenuh, sampling jenuh adalah teknik penentuan sampel bila semua anggota populasi digunakan sebagai sampel.

Jenis data yang digunakan dalam penelitian ini adalah data kuantatif yaitu data yang berupa angka. Untuk mendapatkan data yang diperlukan dalam penelitian ini, peneliti menggukan instrumen berupa tes. Tes digunakan bila peneliti ingin mengukur kemampuan dan kompetensi seseorang (Sugiono 2014). Jenis instrumen yang digunakan adalah tes pilihan ganda. Soal pilihan ganda adalah bentuk tes yang mempunyai satu jawaban yang benar atau paling benar (Sudjana 2014). Teknik analisis data menggunakan analisis deskriptif. Untuk menentukan presentase rata-rata kemampuan membaca pemahaman teks menggunakan rumus statiska sederhana yaitu :

$$
\mathrm{X}=\frac{\sum X i}{n}
$$

Keterangan :

$\mathrm{X}=$ rerata

$\sum X i=$ jumlah nilai siswa keseluruhan

$\mathrm{N} \quad=$ jumlah siswa

Adapun kriteria tingkat kemampuan membaca pemahaman teks siswa kelas v Sekolah Dasar Gugus I Kecamatan Tampan Kota Pekanbaru berdasarkan tolak ukur penilaiannya sebagai berikut:

Tabel 1. Interval Penilaian

\begin{tabular}{ccc}
\hline Interval Presentase & Nilai Ukuran Skala & Keterangan \\
\hline $85-100$ & A & Baik Sekali \\
$70-84$ & B & Baik \\
$50-69$ & C & Cukup \\
$0-49$ & D & Kurang \\
\hline
\end{tabular}

Sumber: Depdiknas ( Liya Simbolon 2017 )

\section{HASIL DAN PEMBAHASAN}

Penelitian ini dilaksanakan di kelas V SD Gugus I Kecamatan Tampan Kota Pekanbaru. Penelitian ini bertujuan untuk mendeskripsikan kemampuan siswa dalam membaca pemahaman teks di kelas V Sekolah Dasar Gugus I Kecamatan Tampan Kota Pekanbaru. Sedangkan Indikator yang dinilai mencakup memahami makna kata dan kalimat, memahami isi dalam paragraf, menentukan ide utama, mengurutkan kalimat yang benar, menyimpulkan teks bacaan.

Dalam pembahasan pada bab ini, peneliti akan menyajikan hasil peneliti tentang kemampuan membaca pemahaman teks siswa kelas V Sekolah Dasar Gugus I Kecamatan Tampan Kota Pekanbaru secara detail pada setiap 
indikator pada kemampuan membaca pemahaman sebagai berikut :

1. Analisis Kemampuan Membaca Pemahaman Teks Siswa Kelas V Sekolah Dasar Gugus I Kecamatan Tampan Kota Pekanbaru dilihat dari Keseluruhan Indikator Per Sekolah Dasar di Gugus I Kecamatan Tampan Kota Pekanbaru
Dalam penelitian ini terdapat 5 Sekolah Dasar yang menjadi sampel penelitian diantaranya ialah Sekolah Dasar Negeri 37 Pekanbaru, Sekolah Dasar Negeri 147 Pekanbaru, Sekolah Dasar Negeri 194 Pekanbaru, Sekolah Dasar Negeri 188 Pekanbaru, Sekolah Dasar Swasta Brilliant Pekanbaru. Tes ini bertujuan untuk melihat kemampuan membaca pemahaman teks yang dapat dilihat pada tabel 2 berikut ini.

Tabel 2. Kemampuan Membaca Pemahaman Teks dilihat dari Keseluruhan Indikator

\begin{tabular}{cccc}
\hline Nama Sekolah Dasar & Kategori & Jumlah Siswa & Rata - rata \\
\hline SDN 37 Pekanbaru & Cukup & 64 Siswa & 64.66 \\
SDN 147 Pekanbaru & Cukup & 111 Siswa & 63.21 \\
SDN 192 Pekanbaru & Cukup & 74 Siswa & 62 \\
SDN 188 Pekanbaru & Cukup & 64 Siswa & 61.4 \\
SDI Brilliant Pekanbaru & Cukup & 30 Siswa & 61.8 \\
\hline
\end{tabular}

Berdasarkan tabel 2 dapat dilihat kemampuan membaca pemahaman teks siswa kelas V Sekolah Dasar Gugus I Kecamatan Tampan Kota Pekanbaru dilihat dari Keseluruhan Indikator Per Sekolah, dari 5 sekolah semuanya mendapatkan kategori yaitu Sekolah Dasar Negeri 37 Pekanbaru dengan perolehan nilai rata - rata 64,66, Sekolah Dasar Negeri 147 Pekanbaru dengan perolehan nilai rata - rata 63,21, Sekolah Dasar Negeri 194 Pekanbaru dengan perolehan nilai rata - rata 62, Sekolah Dasar Negeri 188 Pekanbaru dengan perolehan nilai rata - rata 61,4, dan Sekolah Dasar Brilliant dengan perolehan nilai rata - rata 61,8 .

Selanjutnya penulis akan mendeskripsikan data hasil penelitian mengenai indikator kemampuan membaca pemahaman teks siswa kelas V Sekolah Dasar Gugus I Kecamatan Tampan Kota Pekanbaru.

2. Analisis Kemampuan Membaca Pemahaman Teks Siswa Kelas V Sekolah Dasar Gugus I Kecamatan Tampan Kota Pekanbaru dilihat per Indikator

a) Kemampuan membaca pemahaman teks berdasarkan indikator memahami makna kata dan kalimat

Kemampuan siswa dalam membaca pemahaman teks berdasarkan indikator memahami makna kata dan kalimat di kelas V Sekolah dasar Gugus I Kecamatan Tampan Kota Pekanbaru terlihat pada tabel 3

Tabel 3. Kemampuan Siswa Dalam Membaca Pemahaman Teks Berdasarkan Indikator Memahami Makna Kata Dan Kalimat

\begin{tabular}{cccc}
\hline Interval & Kategori & Jumlah Siswa & Persentase \\
\hline $85-100$ & Baik Sekali & 19 Siswa & $5.53 \%$ \\
$70-84$ & Baik & 122 Siswa & $35.56 \%$ \\
$50-69$ & Cukup & 155 Siswa & $45.18 \%$ \\
$0-49$ & Kurang & 47 Siswa & $13.70 \%$ \\
\hline
\end{tabular}

Berdasarkan tabel 3 Kemampuan siswa dalam membaca pemahaman teks berdasarkan indikator memahami makna kata dan kalimat di kelas V Sekolah Dasar Gugus I Kecamatan Tampan Kota Pekanbaru, dari 343 siswa ada 19 siswa yang mendapatkan kategori baik sekali 
dengan persentase $5.53 \%, 122$ siswa yang mendapatkan kategori baik dengan persentase $35.56 \%, 155$ siswa yang mendapatkan kategori cukup dengan persentase $45.18 \%$, 47 siswa yang mendapatkan kategori kurang dengan persentase $13.70 \%$. Jika dilihat dari nilai rata - rata yang diperoleh pada indikator memahami makna kata dan kalimat yakni sebesar 61.34. Hal ini memberikan gambaran bahwa kemampuan siswa dalam membaca pemahaman teks berdasarkan indikator memahami makna kata dan kalimat tergolong cukup.

b) Kemampuan Membaca Pemahaman Teks Berdasarkan Indikator Memahami Isi Dalam Paragraf

Kemampuan siswa dalam membaca pemahaman teks berdasarkan indikator memahami isi dalam paragraf di kelas V Sekolah Dasar Gugus I Kecamatan Tampan Kota Pekanbaru terlihat pada tabel 4.

Tabel 4. Kemampuan Siswa Dalam Membaca Pemahaman Teks Berdasarkan Indikator Memahami

Isi Dalam Paragraf

\begin{tabular}{cccc}
\hline Interval & Kategori & Jumlah Siswa & Persentase \\
\hline $85-100$ & Baik Sekali & 20 Siswa & $5.83 \%$ \\
$70-84$ & Baik & 128 Siswa & $37.31 \%$ \\
$50-69$ & Cukup & 155 Siswa & $45.18 \%$ \\
$0-49$ & Kurang & 40 Siswa & $11.66 \%$ \\
\hline & & 343 Siswa & $\mathbf{1 0 0}$
\end{tabular}

Berdasarkan tabel 4 Kemampuan siswa dalam memahami isi dalam paragraf di kelas $\mathrm{V}$ Sekolah Dasar Gugus I Kecamatan Tampan Kota Pekanbaru, dari 343 siswa ada 20 siswa yang mendapatkan kategori baik sekali dengan persentase $5,83 \%, 128$ siswa mendapatkan kategori baik dengan persentase 37,31 \%, 155 siswa mendapatkan kategori cukup dengan persentase $45,18 \%, 40$ siswa mendapatkan kategori kurang dengan persentase 11,66 \%. Jika dilihat dari nilai rata - rata yang diperoleh pada indikator memahami isi dalam paragraf yakni sebesar 61.72. Hal ini memberikan gambaran bahwa kemampuan siswa dalam membaca pemahaman teks berdasarkan indikator memahami isi dalam paragraf tergolong cukup.

c) Kemampuan Siswa dalam Membaca Pemahaman Teks Berdasarkan Indikator Menentukan Ide Utama

Kemampuan siswa dalam membaca pemahaman teks berdasarkan indikator menentukan ide utama di kelas V Sekolah Dasar Gugus I Kecamatan Tampan Kota Pekanbaru terlihat pada tabel 5 .

Tabel 5. Kemampuan Siswa Dalam Membaca Pemahaman Teks Berdasarkan Indikator Menentukan

\begin{tabular}{cccc}
\multicolumn{4}{c}{ Ide Utama } \\
\hline Interval & Kategori & Jumlah Siswa & Persentase \\
\hline $85-100$ & Baik Sekali & 24 Siswa & $6.99 \%$ \\
$70-84$ & Baik & 150 Siswa & $43.73 \%$ \\
$50-69$ & Cukup & 135 Siswa & $39.35 \%$ \\
$0-49$ & Kurang & 34 Siswa & $9.91 \%$ \\
\hline & & 343 Siswa & 100 \\
\hline
\end{tabular}

Berdasarkan tabel 5 Kemampuan siswa dalam membaca pemahaman teks berdasarkan indikator menentukan ide utama di kelas $\mathrm{V}$
Sekolah Dasar Gugus I Kecamatan Tampan Kota Pekanbaru, dari 343 siswa ada 24 siswa yang mendapatkan kategori baik sekali dengan 
persentase $6.99 \%, \quad 150$ siswa mendapatkan kategori baik dengan persentase $43.73 \%, 135$ mendapatkan kategori cukup dengan persentase $39.35 \%, 34$ siswa mendapatkan kategori kurang dengan persentase $9.91 \%$. Jika dilihat dari nilai rata - rata yang diperoleh pada indikator menentukan ide utama yakni sebesar 64.72. Hal ini memberikan gambaran bahwa kemampuan membaca pemahaman teks sisa berdasarkan indikator menentukan ide utama tergolong cukup. d) Kemampuan Siswa Dalam Membaca Pemahaman Teks Berdasarkan Indikator Mengurutkan Kalimat yang Benar

Berdasarkan tabel 6 Kemampuan siswa Dalam Membaca Pemahaman Teks Berdasarkan Indikator Mengurutkan Kalimat yang Benar di Kelas V Sekolah Dasar Gugus I Kecamatan Tampan Kota Pekanbaru terlihat pada tabel 6

Tabel 6. Kemampuan Siswa Dalam Membaca Pemahaman Teks Berdasarkan Indikator Mengurutkan Kalimat yang Benar

\begin{tabular}{cccc}
\hline Interval & Kategori & Jumlah Siswa & Persentase \\
\hline $85-100$ & Baik Sekali & 26 Siswa & $7.5 \%$ \\
$70-84$ & Baik & 141 Siswa & $41.10 \%$ \\
$50-69$ & Cukup & 130 Siswa & $37.90 \%$ \\
$0-49$ & Kurang & 46 Siswa & $13.41 \%$ \\
\hline & & 343 Siswa & $\mathbf{1 0 0}$ \\
\hline
\end{tabular}

Berdasarkan tabel 6 kemampuan siswa dalam membaca pemahaman teks berdasarkan Indikator mengurutkan kalimat yang benar di kelas V Sekolah Dasar Gugus I Kecamatan Tampan Kota Pekanbaru, dari 343 siswa ada 26 siswa yang mendapatkan kategori baik sekali dengan persentase $7.5 \%, 141$ siswa mendapatkan kategori baik dengan persentase $41.10 \%, 130$ siswa mendapatkan kategori cukup dengan persentase $37.90 \%$, 46 siswa mendapatkan kategori kurang dengan persentase $13.41 \%$. Jika dilihat dari nilai rata - rata yang diperoleh pada indikator mengurutkan kalimat yang benar yakni sebesar 63.09. Hal ini memberikan gambaran bahwa kemampuan siswa dalam membaca pemahaman teks berdasarkan indikator mengurutkan kalimat yang benar di kelas V Sekolah Dasar Gugus I Kecamatan Tampan Kota Pekanbaru tergolong cukup.

e) Kemampuan Siswa Dalam Membaca Pemahaman Teks Berdasarkan Indikator Menyimpulkan Teks Bacaan

Kemampuan Siswa Dalam Membaca Pemahaman Teks Berdasarkan Indikator Menyimpulkan Teks Bacaan di kelas V Sekolah Dasar Gugus I Kecamatan Tampan Kota Pekanbaru terlihat pada tabel 7.

Tabel 7. Kemampuan Siswa Dalam Membaca Pemahaman Teks Berdasarkan Indikator Menyimpulkan Teks Bacaan

\begin{tabular}{cccc}
\hline Interval & Kategori & Jumlah Siswa & Persentase \\
\hline $85-100$ & Baik Sekali & 24 Siswa & $6.99 \%$ \\
$70-84$ & Baik & 122 Siswa & $35.56 \%$ \\
$50-69$ & Cukup & 146 Siswa & $42.56 \%$ \\
$0-49$ & Kurang & 51 Siswa & $14.86 \%$ \\
\hline & & 343 Siswa & $\mathbf{1 0 0}$ \\
\hline
\end{tabular}

Berdasarkan tabel 7 kemampuan siswa dalam membaca pemahaman teks berdasarkan indikator menyimpulkan teks bacaan di kelas $\mathrm{V}$
Sekolah Dasar Gugus I Kecamatan Tampan Kota Pekanbaru, dari 343 siswa ada 24 siswa yang mendapatkan kategori baik sekali dengan 
persentase $6.99 \%, 122$ siswa mendapatkan kategori baik dengan persentase $35.56 \%, 146$ siswa mendapatkan kategori cukup dengan persentase $42.56 \%, 51$ siswa mendapatkan kategori kurang dengan persentase $14.86 \%$. Jika dilhat dari nilai rata - rata yang diperoleh pada indikator menyimpulkan teks bacaan yakni sebesar 62.36. Hal ini memberikan gambaran bahwa kemampuan siswa dalam membaca pemahaman teks berdasarkan indikator menyimpulkan teks bacaan di kelas V Sekolah Dasar Gugus I Kecamatan Tampan Kota Pekanbaru tergolong cukup.

\section{Analisis Kemampuan Siswa Dalam Membaca Pemahaman Teks di Kelas V Sekolah Dasar Gugus I Kecamatan Tampan Kota Pekanbaru dilihat dari Keseluruhan Indikator}

Kemampuan siswa dalam membaca pemahaman teks di kelas V Sekolah Dasar Gugus I Kecamatan Tampan Kota Pekanbaru secara keseluruhan terlihat pada tabel 8 di bawah ini.

Tabel 8. Kemampuan Siswa Dalam Membaca Pemahaman dilihat dari Keseluruhan Indikator

\begin{tabular}{|c|c|c|c|}
\hline Interval & Kategori & Jumlah & Persentase \\
\hline & & Siswa & \\
\hline $85-100$ & Baik Sekali & 1 Siswa & $0.29 \%$ \\
\hline $70-84$ & Baik & 40 Siswa & $11.66 \%$ \\
\hline $50-69$ & Cukup & 297 Siswa & $86.58 \%$ \\
\hline $0-49$ & Kurang & 5 Siswa & $1.45 \%$ \\
\hline & & 343 Siswa & $100 \%$ \\
\hline
\end{tabular}

Berdasarkan tabel 8 kemampuan siswa dalam membaca pemahaman teks di kelas $\mathrm{V}$ Sekolah Dasar Gugus I Kecamatan Tampan Kota Pekanbaru setelah dianalisis menggunakan nilai yang didapatkan oleh siswa beserta kategorinya, dari 343 siswa hanya 1 siswa mendapatkan kategori baik sekali dengan persentase $0.29 \%, 40$ siswa mendapatkan kategori baik dengan persentase $11.66 \%, 297$ siswa mendapatkan kategori cukup dengan persentase $86.58 \%, 5$ siswa mendapatkan kategori kurang dengan persentase $1.45 \%$.

Hal ini memberikan gambaran bahwa kemampuan siswa kelas V Sekolah Dasar Gugus I Kecamatan Tampan Kota Pekanbaru dalam membaca pemahaman teks secara keseluruhan tergolong cukup.

\section{SIMPULAN DAN REKOMENDASI}

Berdasarkan hasil penelitian yang telah dilakukan oleh peneliti, dapat disimpulkan bahwa kemampuan membaca pemahaman teks di kelas $\mathrm{V}$ Sekolah Dasar Gugus I Kecamatan Tampan Kota Pekanbaru dalam memnbaca pemahaman teks dengan nilai rata - rata 62.75 tergolong cukup. Ada 19 siswa yang mendapatkan persentase 5.53
\% dengan kategori baik sekali, 40 siswa mendapatkan persentase $11.66 \%$ dengan kategori baik, 297 siswa mendapatkan persentase $86.58 \%$ dengan kategori cukup, 5 siswa mendapatkan persentase $1.45 \%$ dengan kategori kurang. Kemampuan siswa ini diperoleh dari hasil tes siswa yang berupa tes berbentuk teks bacaan yang terdiri dari 5 indikator membaca pemahaman teks.

Namun jika dilihat per indikator maka nilai kemampuan siswa dalam membaca pemahaman teks siswa di kelas V Sekolah Dasar Gugus I Kecamatan Tampan Kota Pekanbaru berdasarkan indikator memahami makna kata dan kalimat memperoleh nilai keseluruhan rata - rata 61.34 dengan kategorikan cukup. Kemampuan siswa dalam memahami isi paragraf dengan nilai keseluruhan rata - rata 61.72 dengan kategori cukup. Kemampuan siswa dalam menentukan ide utama dengan nilai keseluruhan rata - rata 64.72 dikategorikan cukup. Kemampuan siswa dalam mengurutkan kalimat yang benar dengan nilai keseluruhan rata - rata 63.09 dengan kategori cukup. Kemampuan siswa dalam menyimpulkan teks bacaan dengan nilai keseluruhan rata - rata 62.36 dengan kategori cukup. 
Berdasarkan hasil penelitian, maka peneliti mangajukan saran kepada pihak yang terkait dengan penelitian ini, antara lain :

1. Siswa agar dapat lebih meningkatkan lagi kemampuan siswa dalam membaca pemahaman teks dalam kategori baik sekali walaupun dalam hasil penelitian ini sudah nencapai kategori cukup dam diharapkan siswa lebih sering lagi membaca agar pengetahuan siswa dalam membaca pemahaman lebih terlatih lagi.

2. Guru hendaknya dapat meningkatkan perhatiannya pada proses membaca anak agar kemampuan anak dalam membaca pemahaman lebih baik lagi

3. Bagi peneltii lanjutan diharapkan melakukan penelitian kemampuan siswa dalam membaca pemahaman terhadap semua bacaan dan diharapkan mampu menjadi referensi sebagai data awal dalam mengambil langkah untuk melakukan penelitian yang lebih dalam lagi mengenai kemampuan membaca pemahaman teks.

\section{DAFTAR PUSTAKA}

Rahim, F. (2011). Pengajaran Membaca Di Sekolah Dasar. Jakarta: Bumi Aksara.

Samsu, S. (2011). Strategi dan Teknik Pembelajaran Membaca. Graha Ilmu: Yogyakarta.

Sugiyono. (2014). Cara Mudah Menyusun: Skripsi, Tesis, Dan Desertasi. Alfabeta: Bandung.

Tarigan, H. G. (2008). Membaca Sebagai Suatu Keterampilan Berbahasa. Angkasa:

Bandung. 